\title{
MOTIVATION OF PREGNANT WOMEN ABOUT BREAST CARE AT PUBLIC HEALTH CENTER PUTRI AYU
}

\author{
Arifarahmi \\ Midwifery Program (Dipl) STIKBA Jambi \\ Email :ami_arifa@yahoo.com
}

\begin{abstract}
Preparation that needs to be done during pregnancy is to do breast care. Breast care aimed to keep breast hygiene, flex and strengthen the nipple, prepare a flat nipple, and prepare ASI production. This is a descriptive research, it aimed to determine the description motivation of pregnant women about breast care at the public health center Putri Ayu Jambi city year 2017. It was conducted on August year 2017. Populations were pregnant women who who visited to check up of pregnancy at the public health center Putri Ayu jambi city on August as many as 38 people. The data collecting used by using questionnaire. Data analyzed as univariate.The result showed that respondents had low motivation were 18 respondents (47\%) and respondents who had high motivation were 20 respondents (53\%). Respondents who did not breast care were 16 respondents (42.1\%) and respondents who breast care were 22 (54\%).For the health personnel expected to improve of counseling to pregnant women during antenatal care service or pregnant women class.
\end{abstract}

Keywords : Motivation, Breast Care, Pregnant

\begin{abstract}
ABSTRAK
Persiapan yang perlu dilakukan pada maasa kehamilan yaitu dengan melakukan perawatan payudara. Perawatan payudara bertujuan untuk memelihara kebersihan payudara, melenturkan dan menguatkan puting susu, menyiapkan puting yang masuk kedalam atau datar, serta menyiapkan produksi ASI. Penelitian ini merupakan deskriptif untuk mengetahui gambaran motivasi ibu hamil tentang perawatan payudara di Puskesmas Putri Ayu tahun 2017. Penelitian dilaksanakan pada bulan Agustus Tahun 2017. Populasi adalah ibu hamil yang berkunjung melakukan pemeriksaan kehamilan di Puskesmas Putri Ayu Kota Jambi bulan Agustus yang berjumlah 62 orang, sampel diambil dengan teknik purposive sampling yang berjumlah 38 orang. Pengumpulan data menggunakan kuesioner. Data yang terkumpul dianalisis secara univariat. Hasil penelitian menunjukkan bahwa responden yang memiliki motivasi rendah yaitu 18 responden $(47 \%)$ dan responden yang memiliki motivasi tinggi yaitu 20 responden $(53 \%)$. Responden yang tidak melakukan perawatan payudara yaitu 16 responden $(42,1 \%)$ dan responden yang melakukan perawatan payudara yaitu 22 responden (54\%).Bagi petugas kesehatan diharapkan meningkatkan penyuluhan dan konseling bagi ibu hamil saat pelayanan antenatal care atau dengan membentuk kelas ibu hamil.

Kata Kunci : : Motivasi, Perawatan Payudara, Ibu Hamil
\end{abstract}




\section{PENDAHULUAN}

Angka kematian ibu dan bayi merupakan tolak ukur dalam menilai kesehatan suatu bangsa. Oleh sebab itu, melalui berbagai program kesehatan, pemerintah berupaya menurunkan angka kematian ibu dan bayi. Kematian hingga saat ini masih menjadi masalah utama dalam bidang kesehatan ibu dan anak (Lockhart, 2014).

Komplikasi yang menjadi penyebab kematian bayi terbanyak adalah Infeksi Saluran Pernapasan Atas (ISPA) dan diare, hal tersebut dapat dicegah antara lain dengan pemberian ASI secara benar dan tepat. Maka dari itu pemberian Air Susu Ibu (ASI) dilakukan seketika setelah bayi lahir, karena ASI merupakan makanan terbaik bagi bayi yang mampu memberikan perlindungan baik secara aktif maupun pasif, ASI mengandung zat anti infeksi yang akan melindungi bayi dari berbagai macam infeksi, baik yang disebabkan oleh bakteri, virus, jamur atau parasit (Wiji, 2013).

World Health Organization telah merekomendasikan untuk menyusui secara eksklusif dalam 6 bulan pertama kehidupan bayi dan melanjutkannya untuk waktu dua tahun atau lebih, karena ASI sangat seimbang dalam memenuhi kebutuhan nutrisi bayi yang baru lahir dan merupakan satu-satunya makanan yang dibutuhkan sampai usia enam bulan (Pollard, 2016).

Persiapan menyusui pada masa kehamilan merupakan hal yang penting karena dengan persiapan dini ibu akan lebih baik dan siap untuk menyusui bayinya (Rukiyah,
2013). Persiapan dini yang perlu dilakukan yaitu dengan melakukan perawatan payudara. Perawatan payudara bertujuan untuk memelihara kebersihan payudara, melenturkan dan menguatkan puting susu, menyiapkan puting yang masuk kedalam atau datar, serta menyiapkan produksi ASI. Sejumlah prinsip yang perlu diperhatikan dalam perawatan payudara meliputi proses pengerjaan yang sistematis dan teratur, menjaga kebersihan sehari-hari, nutrisi harus lebih baik dari sebelum hamil, menggunakan bra yang bersih dan menopang payudara serta dilakukan pada usia kehamilan lebih dari 6 bulan (Astuti dkk, 2016).

Pada saat ini, tidak sedikit ibu hamil yang mengabaikan perawatan payudara saat hamil, baik itu karena ibu merasa malas atau mungkin belum mengetahui manfaat perawatan payudara akan berpengaruh pada saat menyusui. Bentuk payudara selama kehamilan akan mengalami perubahan, seperti terasa lebih kencang, lebih besar, dan lebih penuh. Bahkan ketika akan melahirkan payudara wanita akan membesar 1,5 kali dibandingkan sebelum hamil. Untuk itu, selain untuk meningkatkan kelancaran ASI, perawatan payudara selama hamil juga bermanfaat dalam mempertahankan bentuk payudara ibu selama menyusui (Lockhart, 2014).'

Perawatan payudara yang tidak dilakukan dengan baik sering menyebabkan berbagai kasus yang merugikan ibu dan bayi. Kasus yang sering terjadi ASI tidak keluar, puting susu tidak menonjol, produksi ASI sedikit, infeksi pada payudara 
dan muncul benjolan pada payudara (Lockhart, 2014). Perawatan payudara selama hamil memiliki banyak manfaat yaitu menjaga kebersihan payudara terutama kebersihan puting susu, melenturkan dan menguatkan puting susu sehingga memudahkan bayi untuk menyusu, merangsang kelenjar air susu untuk memproduksi ASI sehingga ASI yang dihasilkan banyak dan lancar, mendeteksi kelainan payudara secara dini dan mempersiapkan mental ibu untuk menyusui (Astuti, 2016).

\section{METODE PENELITIAN}

Penelitian ini merupakan penelitian deskriptif. Penelitian dilaksanakan pada bulan Agustus Tahun 2017. Populasi penelitian ini adalah ibu hamil yang berkunjung untuk melakukan pemeriksaan kehamilan di Puskesmas Putri Ayu Kota Jambi yang berjumlah 62 orang. Sampel dengan teknik purposive sampling berjumlah 38 orang. Pengumpulan data dengan menggunakan kuesioner. Data yang terkumpul dianalisis secara univariat

\section{HASIL DAN PEMBAHASAN}

\section{Karakteristik responden}

a. Umur

Karakteristik responden berdasarkan umur dapat dilihat dari tabel berikut:

Tabel 1. Karakteristik Responden Berdasarkan Umur Ibu Hamil

\begin{tabular}{cccc}
\hline NO & Umur Ibu & f & \% \\
\hline 1. & $20-35$ Tahun & 36 & 94.7
\end{tabular}

2. > 35 Tahun $2 \quad 5.3$

Jumlah $\quad 38 \quad 100$

b. Tingkat Pendidikan

Tabel 2. Karakteristik

Responden Berdasarkan Tingkat Pendidikan Ibu Hamil

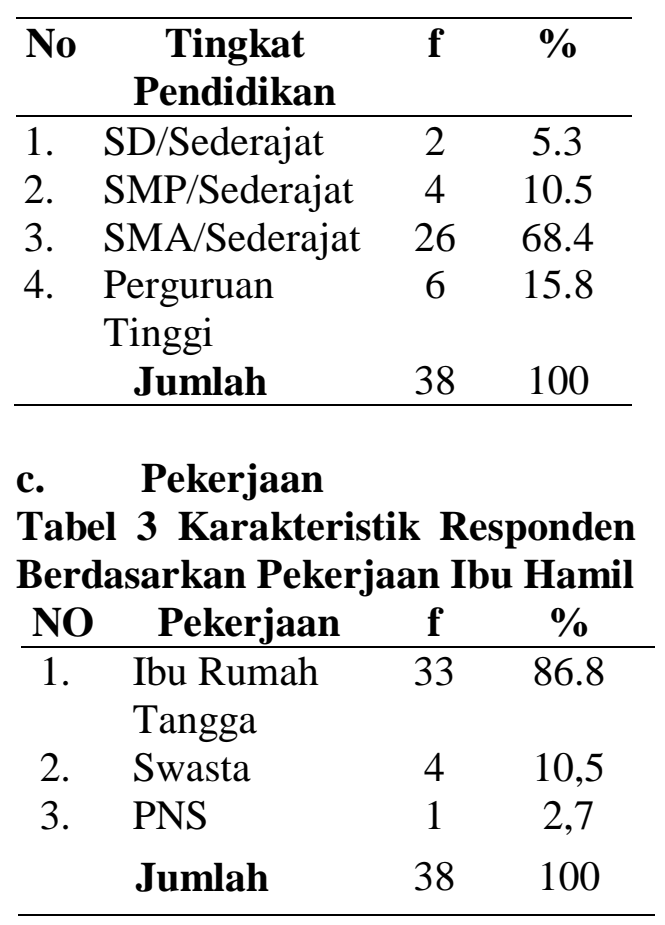

2. Analisis Univariat

a. Motivasi Ibu Hamil

Tentang Perawatan Payudara

Diagram 1. Motivasi Ibu Hamil tentang Perawatan Payudara

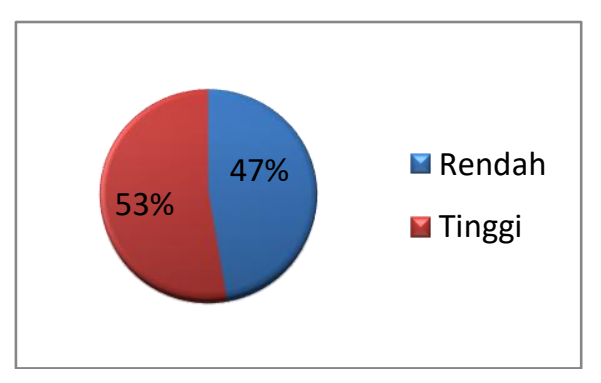


b. Gambaran Perawatan Payudara pada Ibu Hamil

\section{Diagram 2. Perawatan Payudara Pada Ibu Hamil}

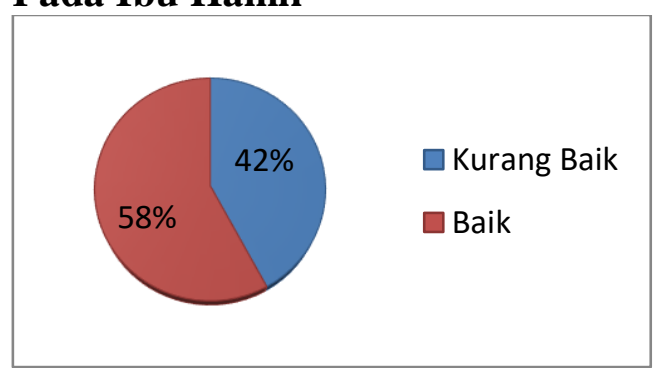

\section{Pembahasan}

\section{Gambaran Motivasi Ibu Hamil tentang Perawatan Payudara di Puskesmas Putri Ayu Kota Jambi Tahun 2017}

Berdasarkan hasil penelitian, dari 38 responden bahwa responden yang memiliki motivasi rendah yaitu 18 responden (47\%) dan responden yang memiliki motivasi tinggi yaitu 20 responden $(53 \%)$.

Motivasi adalah suatu usaha yang disadari untuk mempengaruhi tingkah laku seseorang agar ia bergerak hatinya untuk bertindak melakukan sesuatu sehingga mencapai hasil dan tujuan tertentu (Notoatmodjo, 2010). Faktor-faktor yang mempengaruhi motivasi yaitu faktor intrinsik dan faktor ekstrinsik. Faktor instrinsik adalah motivasi yang tidak dipengaruhi oleh faktorfaktor dari luar tetapi di dalam diri individu tersebut sudah terdapat dorongan untuk melakukan sesuatu sedangkan Faktor ekstrinsik adalah motivasi yang ada karena dipengaruhi oleh faktor-faktor dari luar diri individu tersebut (lingkungan).

Dari hasil analisa didapat bahwa terdapat ibu hamil yang memiliki motivasi tinggi namun tidak melakukan peawatan payudara.
Hal ini menunjukkan dengan motivasi yang tinggi namun tidak dengan pengetahuan yang baik ibu tidak dapat melakukan perawatan payudara karena tidak mengetahui tahap-tahapnya. Sebaliknya terdapat motivasi yang kurang namun melakukan perawatan payudara yang baik karena ibu memiliki pengetahuan dan dukungan dari keluarga dan petugas yang baik sehingga ibu melakukan perawatan payudara.

Berdasarkan penjelasan diatas terlihat bahwa responden mempunyai motivasi tinggi dalam melakukan perawatan payuadara. Tingginya motivasi responden dipengaruhi pengetahuan dan pengalaman yang pernah dilakukan responden maupun dipengaruhi melalui pemberian informasi dari petugas kesehatan. Dengan pengetahuan yang baik tentang perawatan payudara maka akan lebih meningkatkan motivasi untuk melakukan perawatan payudara sehingga dapat memperkecil kemungkinan terjadinya masalah pada payudara.

Sedangkan masih terdapat responden yang masih memiliki motivasi rendah. Rendahnya motivasi responden dapat dipengaruhi faktor dari dalam diri responden yaitu kurangnya pengetahuan ibu mengenai perawatan payudara selain itu pengalaman ibu yang belum pernah hamil juga dapat membuat motivasi ibu menjadi rendah untuk melakukan perawatan payudara Motivasi responden juga dapat dipengaruhi faktor dari luar responden yaitu pemberian informasi dari keluarga maupun petugas kesehatan. 
Kurangnya dukungan dari keluarga dan petugas kesehatan juga dapat mempengaruhi motivasi ibu menjadi kurang untuk melakukan perawaan payudara.

Maka dari itu, untuk membentuk motivasi seseorang maka sebaiknya ditanamkan dari dalam individu responden dengan mempengaruhinya melalui pemberian informasi mengenai perawatan payudara, maka dengan dengan pengaruh yang diberikan maka akan lebih membuat ibu melaksanakan perawatan payudara dengan baik.

Responden yang mempunyai motivasi tinggi terhadap perawatan payudara dikarenakan adanya pengetahuan yang dimiliki serta dorongan dari petugas kesehatan dan keluarga untuk mendukung ibu agar ibu melakukan perawatan payudara. Sedangkan motivasi responden yang rendah dipengaruhi oleh pengetahuan yang rendah sehingga ibu tidak mengetahui perawatan payudara yang benar, tidak ada dukungan dari keluarga dan tidak dipraktekkan oleh petugas kesehatan merupakan faktor ibu tidak mempunyai motivasi yang tinggi untuk melakukan perawatan payudara.

Upaya yang dilakukan adalah diharapkan kepada petugas kesehatan selalu ikut berperan aktif dalam memotivasi responden agar dapat melakukan perawatan payudara agar tidak terjadi masalah dalam menyusui melalui konseling dan mencontohkan atau mempraktekkan cara melakukan perawatan payudara dengan benar. Selain itu sebaiknya pihak Puskesmas menyediakan poster- poster mengenai perawatan payudara.

2. Gambaran Perawatan Payudara pada Ibu Hamil di Puskesmas Putri Ayu Kota Jambi Tahun 2017

\section{Hasil}

penelitian menunujukkan bahwa responden yang tidak melakukan perawatan payudara yaitu 16 responden $(42 \%)$ dan responden yang melakukan perawatan payudara yaitu 22 responden $(58 \%)$.

Responden yang melakukan perawatan payudara dengan baik karena responden telah mendapatkan informasi dari tenaga kesehatan mengenai perawatan payudara selain itu pendidikan terakhir responden juga dapat mempengaruhi kemampuan responden dalam melakukan perawatan payudara karena dengan tingginya tingkat pendidikan responden membuat responden lebih banyak mencari informasi mengenai perawatan payudara. Maka responden yang melakukan perawatan payudara dengan baik dipengaruhi oleh pengetahuan yang dimiliki mengenai perawatan payudara sehingga dengan pengetahuan yang baik akan memotivasi responden untuk melakukan perawatan payudara dengan baik.

Perawatan payudara selama kehamilan adalah salah satu bagian penting yang harus diperhatikan sebagai persiapan dalam pemberian ASI. Tetapi sebagian besar para ibu hamil tidak melakukan perawatan payudara karena kurangnya pengetahuan dan motivasi dalam 
perawatan payudara itu sendiri. Walaupun ada ibu yang melakukan perawatan payudara, perilaku dan tehnik yang di lakukan pun belum benar.Ibu-ibu hamil tidak akan mengalami kesulitan dalam pemberian ASI bila sejak awal telah mengetahui bagaimana perawatan payudara yang tepat dan benar (Wiji, 2013).

Masih kurangnya perilaku perawatan payudara salah satunya dipengaruhi oleh informasi yang kurang di dapat ibu. Kurangnya informasi yang didapat ibu karena ibu jarang mendengarkan konseling yang diberikan tenaga kesehatan mengenai perawatan payudara. Dapat dilihat dari analisa pekerjaan responden sebagian besar tidak bekerja yaitu sebagai Ibu Rumah Tangga sehingga informasi mengenai perawatan payudara sulit didapat terlebih lagi ibu tersebut jarang untuk mencari informasi melalui media baik buku maupun media internet, namun masih ada responden yang melakukan perwatan payudara sudah mendapatkan informasi yang lengkap mengenai perawatan payudara yang didapat ibu melalui media internet maupun konseling pada petugas kesehatan.

Berdasarkan penjelasan diatas terlihat bahwa masih banyak responden yang tidak melakukan perawatan payudara dengan baik. Perilaku perawatan payudara dipengaruhi oleh pengetahuan dan motivasi yang dimiliki responden untuk mencari informasi mengenai perawatan payudara agar nantinya ibu dapat langsung menyusui bayi setelah melahirkan. Selain itu peningkatan pengetahuan dan mengajak ibu untuk melakukan perawatan payudara oleh petugas kesehatan sangat membantu ibu dalam perilaku perawatan payudara. Dengan pengetahuan dan motivasi yang baik tentang perawatan payudara maka akan membantu ibu agar ibu merawat payudara dengan baik sehingga dapat memperlancar ASI ibu dan ibu dapat menyusui bayi setelah melahirkan dan tidak mengalami masalah-masalah dalam menyusui bayinya.

\section{SIMPULAN}

Berdasarkan hasil penelitian dapat disimpulkan sebagai berikut:

1. Ibu hamil yang memiliki motivasi rendah yaitu 18 ibu hamil (47\%) dan ibu hamil yang memiliki motivasi tinggi yaitu 20 ibu hamil $(53 \%)$.

2. Ibu hamil yang tidak melakukan perawatan payudara yaitu 16 ibu hamil (42\%) dan ibu hamil yang melakukan perawatan payudara yaitu 22 ibu hamil (58\%).

\section{SARAN}

\section{Bagi Puskesmas Putri Ayu}

Bagi Puskesmas Putri Ayu untuk meningkatkan penyuluhan dan konseling bagi ibu hamil saat pelayanan antenatal care atau dengan meningkatkan dukungan suami untuk mendukung ibu dalam perawatan payudara dengan mengikutsertakan suami dalam pelaksanaan kelas ibu hamil.

\section{Bagi peneliti lain}

Diharapkan bagi peneliti lain yang ingin melanjutkan penelitian 
ini agar dapat melakukan variabel yang berbeda misalnya dengan mencari faktor-faktor yang dapat mempengaruhi perawatan payudara dengan memperbanyak ibu hamil sebagai sampel serta lebih memperdalam kualitas pertanyaan pada kuesioner.

\section{DAFTAR PUSTAKA}

1. Astuti. 2016. Asuhan Ibu Dalam Masa Kehamilan. Erlangga. Jakarta

2. Badriah, Dewi, L, Gizi Dalam Kesehatan Reproduksi. Refika Aditama. Jakarta

3. Dinas Kesehatan Kota Jambi. 2016. Cakupan Pelayanan Antenatal di Kota Jambi Tahun 2016. Kota Jambi

4. Haryono, R., Sulis, S. (2014). Manfaat ASI Eksklusif. Yogyakarta: Gosyen Publishing.

5. Hidayat, Aziz. 2010. Metode Penelitian Kebidanan Dan Teknik Analisis Data. Penerbit Salemba Medika. Jakarta.

6. Hutahaean. 2013. Perawatan antenatal. Salemba Medika. Jakarta.

7. Kemenkes RI. 2015. Profil Kesehatan Indonesia Tahun 2015. Jakarta

8. Kemenkes RI. 2010. Pedoman Pemantauan Wilayah Setempat Kesehatan Ibu dan Anak (PWSKIA). Jakarta

9. Lockhart dan Lyndon. 2014. Kehamilan Fisiologis dan Patologis. Bina Pura aksara. Jakarta.

10. Notoatmodjo, S. 2012. Promosi Kesehatan dan Perilaku Kesehatan. PT Rineka Cipta. Jakarta.

11. Notoatmodjo, S. 2010.Ilmu Perilaku kesehatan. Asdi Mahasatya.Jakarta.

12. Notoatmodjo, S. 2010.Metode Penelitian Kesehatan,PT Rineka Cipta.Jakarta.
13. Pantikawati, Ika. 2010. Asuhan Kebidanan I (Kehamilan). Nuha Medika. Yogyakarta.

14. Pollard, M. 2015. ASI Asuhan Berbasis Bukti. Jakarta: EGC.

15. Rukiyah, 2013. Asuhan Kebidanan I (Kehamilan). Trans Info Media. Jakarta.

16. Sari. 2015. Pengetahuan Ibu Hamil Trimester III tentang Perawatan Payudara di Klinik Pratama Bina Sehat Kasihan Bantul Yogyakarta. Jurnal. Sekolah Tinggi Ilmu Kesehatan Alma Ata Yogyakarta.

17. Saminem. 2009. Dokumentasi Asuhan Kebidanan Konsep Dan Praktik. EGC. Jakarta:

18. Wiji, Rizki,. N. 2013. ASI dan Panduan Ibu Menyusui. Nuha Medika. Yogyakarta.

19. Yuliana. 2012. Tingkat Pengetahuan Ibu Primigravida tentang Perawatan Payudara di BPS Sunarsi Kabupaten Sragen. Jurnal. Jurusan D III Kebidanan STIKES Kusuma Husada Surakarta 